NASA/TM-2010-216912

\title{
Examination of Icing Induced Loss of Control and Its Mitigations
}

Andrew L. Reehorst, Harold E. Addy, Jr., and Renato O. Colantonio

Glenn Research Center, Cleveland, Ohio 


\section{NASA STI Program . . . in Profile}

Since its founding, NASA has been dedicated to the advancement of aeronautics and space science. The NASA Scientific and Technical Information (STI) program plays a key part in helping NASA maintain this important role.

The NASA STI Program operates under the auspices of the Agency Chief Information Officer. It collects, organizes, provides for archiving, and disseminates NASA's STI. The NASA STI program provides access to the NASA Aeronautics and Space Database and its public interface, the NASA Technical Reports Server, thus providing one of the largest collections of aeronautical and space science STI in the world. Results are published in both non-NASA channels and by NASA in the NASA STI Report Series, which includes the following report types:

- TECHNICAL PUBLICATION. Reports of completed research or a major significant phase of research that present the results of NASA programs and include extensive data or theoretical analysis. Includes compilations of significant scientific and technical data and information deemed to be of continuing reference value. NASA counterpart of peer-reviewed formal professional papers but has less stringent limitations on manuscript length and extent of graphic presentations.

- TECHNICAL MEMORANDUM. Scientific and technical findings that are preliminary or of specialized interest, e.g., quick release reports, working papers, and bibliographies that contain minimal annotation. Does not contain extensive analysis.

- CONTRACTOR REPORT. Scientific and technical findings by NASA-sponsored contractors and grantees.
- CONFERENCE PUBLICATION. Collected papers from scientific and technical conferences, symposia, seminars, or other meetings sponsored or cosponsored by NASA.

- SPECIAL PUBLICATION. Scientific, technical, or historical information from NASA programs, projects, and missions, often concerned with subjects having substantial public interest.

- TECHNICAL TRANSLATION. Englishlanguage translations of foreign scientific and technical material pertinent to NASA's mission.

Specialized services also include creating custom thesauri, building customized databases, organizing and publishing research results.

For more information about the NASA STI program, see the following:

- Access the NASA STI program home page at http://www.sti.nasa.gov

- E-mail your question via the Internet to help@ sti.nasa.gov

- Fax your question to the NASA STI Help Desk at $443-757-5803$

- Telephone the NASA STI Help Desk at 443-757-5802

- Write to: NASA Center for AeroSpace Information (CASI) 7115 Standard Drive Hanover, MD 21076-1320 
NASA/TM-2010-216912

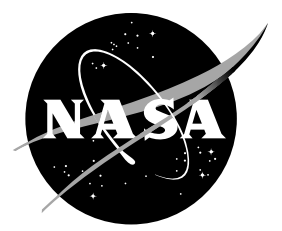

\section{Examination of Icing Induced Loss of Control and Its Mitigations}

Andrew L. Reehorst, Harold E. Addy, Jr., and Renato O. Colantonio

Glenn Research Center, Cleveland, Ohio

Prepared for the

Atmospheric and Space Environments Conference

sponsored by the American Institute of Aeronautics and Astronautics

Toronto, Ontario, Canada, August 2-5, 2010

National Aeronautics and

Space Administration

Glenn Research Center

Cleveland, Ohio 44135 
Level of Review: This material has been technically reviewed by technical management.

Available from

NASA Center for Aerospace Information

7115 Standard Drive

Hanover, MD 21076-1320
National Technical Information Service 5301 Shawnee Road Alexandria, VA 22312

Available electronically at http://gltrs.grc.nasa.gov 


\title{
Examination of Icing Induced Loss of Control and Its Mitigations
}

\author{
Andrew L. Reehorst, Harold E. Addy, Jr., and Renato O. Colantonio \\ National Aeronautics and Space Administration \\ Glenn Research Center \\ Cleveland, Ohio 44135
}

\begin{abstract}
Factors external to the aircraft are often a significant causal factor in loss of control (LOC) accidents. In today's aviation world, very few accidents stem from a single cause and typically have a number of causal factors that culminate in a LOC accident. Very often the "trigger" that initiates an accident sequence is an external environment factor. In a recent NASA statistical analysis of LOC accidents, aircraft icing was shown to be the most common external environmental LOC causal factor for scheduled operations. When investigating LOC accident or incidents aircraft icing causal factors can be categorized into groups of 1) in-flight encounter with super-cooled liquid water clouds, 2) take-off with ice contamination, or 3) in-flight encounter with high concentrations of ice crystals. As with other flight hazards, icing induced LOC accidents can be prevented through avoidance, detection, and recovery mitigations. For icing hazards, avoidance can take the form of avoiding flight into icing conditions or avoiding the hazard of icing by making the aircraft tolerant to icing conditions. Icing detection mitigations can take the form of detecting icing conditions or detecting early performance degradation caused by icing. Recovery from icing induced LOC requires flight crew or automated systems capable of accounting for reduced aircraft performance and degraded control authority during the recovery maneuvers. In this report we review the icing induced LOC accident mitigations defined in a recent LOC study and for each mitigation describe a research topic required to enable or strengthen the mitigation. Many of these research topics are already included in ongoing or planned NASA icing research activities or are being addressed by members of the icing research community. These research activities are described and the status of the ongoing or planned research to address the technology needs is discussed.
\end{abstract}

\section{Introduction}

\section{Loss of Control Study}

In July of 2009, Dr. Amy Pritchett, the NASA Aviation Safety Program (AvSP) Program Director, initiated a study of the fundamental research required to address aircraft loss of control. The study team was chartered to "identify and prioritize the most important research activities needed to address the loss of control problem, considering research relevant to helping avoid loss of control situations in the first place, detect them if they should occur, and then safely recover from them (automatically or manually)" (Pritchett). The team was further directed to examine LOC from both a short-term and long-term perspective, identifying research activities that could have rapid impact as well as those that address the evolving nature of aviation, such as NextGen airspace concepts and emerging advanced flight technologies.

A team of seven members from four NASA research centers interviewed subject matter experts and reviewed loss of control accident reports, previous LOC studies, and statistical analyses. Based upon these investigations and experience in the related research topic areas, the team then developed a list of key mitigations and related research topics, and published a findings and recommendations document (Jacobson). 


\section{Aircraft Icing as a Loss of Control Trigger}

"Loss of control includes significant, unintended departure of the aircraft from controlled flight, the operational flight envelope, or usual flight attitudes, including ground events" (Jacobson). Factors external to the aircraft are often a significant causal factor in loss of control accidents. In today's aviation world, very few accidents have a single cause, but rather a number of causal factors must be lined up to cause a loss of control accident. Very often the "trigger" that initiates an accident sequence is an external environmental factor.

Arguably, the most significant environmental hazard for triggering LOC accidents is icing. Based upon a review of National Transportation Safety Board (NTSB), Federal Aviation Administration (FAA), and NASA database information (Reveley), icing was a causal factor in 54 percent of Part 121 and scheduled Part 135 LOC accidents (out of a total of 40), 27 percent of unscheduled Part 135 LOC accidents (out of a total of 159), and 6 percent of Part 91 LOC accidents (out of a total of 4287) Note: Our definition of icing as a causal factor includes the "WX - Icing", "Inadequate Ice/Frost Removal", and a portion of "WX - Snow/Rain" Causal Factors from the Reveley report.

By its very nature, icing can induce a LOC accident by way of many paths. For example: a severe ice accretion can cause such drastic aerodynamic degradation that the aircraft becomes uncontrollable; icing can cause a drag increase such that an inattentive flight crew lets the speed degrade to wing stall; or an ice accretion can limit control effectiveness so that in an emergency maneuver the aircraft becomes uncontrollable. While all of these accident scenarios would play out very differently, they can all be described as being triggered by the aircraft's initial encounter with atmospheric icing conditions.

Just as the icing environmental trigger can cause different accident scenarios, the resultant loss of control accident could be prevented through several potential mitigations. The icing environment can ideally be completely avoided. Since avoidance results in the lowest potential for harm to the aircraft its crew and passengers, it is the preferred option. However, avoidance is often impractical and rarely 100 percent effective, with inadvertent exposure always a possibility, so reliance on either ice protection (avoidance of the icing hazard by designing in robustness) or early detection and exit are the next best strategies. If both the avoidance and detection options are missed, the final possible mitigation to prevent a loss of control accident is recovery. Since the level of risk increases as a potential accident scenario plays out and the number of potential mitigations correspondingly decreases, the earlier a loss of control causal factor is mitigated, the better. Therefore, the avoidance mitigations are almost always preferred over detection and recovery. Accordingly, research to enable avoidance mitigations (avoiding the icing conditions completely or avoiding the icing hazard through ice protection technologies) should in general be favored over those of detection and recovery where other factors are equal. Similarly, detection mitigation related research should be favored over that required for recovery mitigations. Other factors to be considered in prioritizing research include such things as probability of success, expected time to implementation, and cost and likelihood of implementation.

For the text that follows, the avoidance, detection, and recovery mitigations will be further refined to explain exactly what is being avoided, detected, or recovered from. For example, when icing causes a loss of airspeed leading to loss of control we can avoid the icing conditions altogether or we can make the aircraft tolerant of ice (with an appropriate ice protection system). Both mitigations avoid the hazard, but are very different from one another. Similarly, we can detect the ice accretion or we can detect the resulting low airspeed condition.

\section{Icing Causal Factors}

The loss of control causal factor of icing is actually made up of several different hazards that lead to accidents:

1. Inflight ice accretion that causes aircraft performance degradation and a subsequent LOC. Icing build up on an aircraft will lead to increased drag, which slows the vehicle or requires an increase in thrust to maintain speed. Additionally, ice accretion on wing surfaces leads to an 
increase in the stall speed and a reduction in stall angle-of-attack. The combination of these factors can lead to an unintentional stall upset.

2. Attempted takeoff with snow and ice that built up while the aircraft was on the ground that prevents the aircraft from achieving sufficient flight speeds. During ground operations snow and ice can accumulate on aircraft surfaces quickly resulting in an unsafe condition for takeoff. Ground ice contamination may occur after the airplane has already been de-iced and the crew is confident that their vehicle is flight worthy. Ground ice contamination is fundamentally different than that accreted inflight. The contamination can be located anywhere on the airframe and may or may not be actually adhering to the surface.

3. Ice accretions cause flight control difficulties due to degraded aerodynamics over the flight control surfaces. Surfaces may lose control effectiveness or have nonlinear dynamics characteristics leading to a vehicle that is difficult or impossible to manually control.

4. Engine ingestion of shed ice, ingestion of high levels of ice crystals, or carburetor icing can cause power loss and asymmetric thrust leading to LOC. There are many examples in the accident databases that describe loss of control events following propulsion system failure. While often not directly causing loss of control, propulsion system failure is often the "trigger" event. The actual loss of control can be caused by asymmetric thrust, insufficient airspeed, flight crew distraction, or several other causal factors.

5. Either inflight or ground icing can cause complete airdata system failure when the pitot or static pressure ports become blocked. A number of recent accidents may be attributed to false airspeed and altitude measurements due to blockage of the air data ports.

Some form of icing causes each of these hazards, but each hazard is unique and generally requires a different form of mitigation. Historically icing has been considered primarily an inflight aircraft performance issue. However, a review of the accident databases reveals that all forms of the icing hazard occur with alarming frequency. Table 1 provides accident references for each of these icing hazard categories.

TABLE 1.-CATEGORIES OF ICING FLIGHT HAZARDS AND EXAMPLE ACCIDENT INFORMATION

\begin{tabular}{|c|c|c|c|}
\hline \multirow[t]{2}{*}{ Category of icing } & \multicolumn{3}{|c|}{ Accident identification information } \\
\hline & Site & Aircraft & Year \\
\hline \multirow{6}{*}{$\begin{array}{l}\text { Inflight icing induced airspeed } \\
\text { loss below stall speed }\end{array}$} & Buffalo, NY & DHC-8 & 2009 \\
\hline & Santa Maria, CA & Saab 340 & 2006 \\
\hline & Pueblo, $\mathrm{CO}$ & Cessna 560 & 2005 \\
\hline & Moscow, Russia & Cessna 206 & 2005 \\
\hline & West Palm, FL & EMB-120 & 2001 \\
\hline & Monroe, MI & EMB-120 & 1997 \\
\hline \multirow{5}{*}{$\begin{array}{l}\text { Takeoff with snow and ice } \\
\text { contamination }\end{array}$} & Montrose, $\mathrm{CO}$ & CL-600 & 2004 \\
\hline & Baotou, China & CRJ-200 & 2004 \\
\hline & Flushing, NY & F-28 & 1992 \\
\hline & Cleveland, $\mathrm{OH}$ & DC-9 & 1991 \\
\hline & Denver, CO & DC-9 & 1987 \\
\hline \multirow{3}{*}{$\begin{array}{l}\text { Flight control difficulties caused } \\
\text { by ice contamination induced } \\
\text { aerodynamic disruption }\end{array}$} & Roselawn, IN & ATR-72 & 1994 \\
\hline & Beckley, WV & Jetstream 31 & 1991 \\
\hline & Stockholm, Sweden & Vickers Viscount & 1977 \\
\hline \multirow{5}{*}{$\begin{array}{l}\text { Propulsion system degradation } \\
\text { caused by engine ingestion of } \\
\text { shed ice, ingestion of high levels } \\
\text { of ice crystals, or carburetor } \\
\text { icing }\end{array}$} & Wichita Falls, TX & Champion & 2008 \\
\hline & Ft. Yukon, AK & Cessna 550 & 2005 \\
\hline & Machiques, Venezuela & MD-82 & 2005 \\
\hline & Sarasota, FL & Beechjet 400 & 2004 \\
\hline & Gottora, Sweden & MD-81 & 1991 \\
\hline \multirow{5}{*}{$\begin{array}{l}\text { Air data system failure caused by } \\
\text { ice blockage }\end{array}$} & Kagoshima, Japan & A330 & 2009 \\
\hline & Wellsville, MO & PA-46 & 2007 \\
\hline & Union Star, MO & B-717 & 2005 \\
\hline & Flushing, NY & MD-82 & 1994 \\
\hline & Washington, DC & B-737 & 1982 \\
\hline
\end{tabular}




\section{Mitigating the Aircraft Icing Hazard}

To some degree, each of these icing hazards can be mitigated through avoidance, detection, and recovery. Some mitigations, such as the avoidance of icing conditions through the use of improved weather information, can be applicable to all forms of icing hazard. While other mitigations, such as the detection of air data system ice blockage, are very specific to a particular icing hazard. Table 2 provides a detailed listing of the icing hazards, mitigations, and associated research topics developed during the NASA LOC Study. In general the mitigations can be broken down into the following areas:

1. Avoidance of icing conditions (inflight supercooled liquid or ice crystals, or ground level freezing or frozen precipitation) or icing-conducive weather through the use of improved weather information. The improved weather knowledge can be a result of improved icing nowcast and forecast products or the use of remote airborne or ground-based icing weather sensors.

2. Avoidance of icing conditions with enhanced training. Whether it be for the flightcrew, airline dispatchers, or air traffic controllers, enhanced knowledge of the icing environment, its impact to aircraft, and methods for avoidance would help mitigate the risk of icing accidents by allowing better go/no-go and routing decisions.

3. Avoidance of icing induced performance and controllability degradation by making aircraft more icing tolerant. Through their design and equipage, modern commercial aircraft can today safely operate in a wide range of known icing conditions. Through the use of improved empirical and computational design methods and advanced ice protections technologies, existing aircraft types can be manufactured to be tolerant of greater levels of icing severity, and new, emerging aircraft technologies can be engineered to be ice tolerant earlier in the design process. The flight control system can be designed to be more tolerant of ice contamination and be capable of adapting itself to changing control authority and envelope limits. Also, the design standards can be improved as we gain a better understanding of the range of icing conditions that can be encountered. As global route coverage expands and the volume of traffic increases rare and geographically specific icing conditions must be accounted for to maximize fleet safety.

4. Detection of ice build-up with sensor systems. The various forms of icing hazard require different forms of instrumentation due to the nature of their ice accretion (inflight icing primarily needs very sensitive detection with leading edge coverage, ground icing requires detection with entire airframe coverage, engine icing requires detection in very small, possibly rotating locations, and airdata icing detection requires quick detection of port or line blockage). All forms of detection must also be annunciated to the flightcrew in an unambiguous manner that does not cause unnecessary workload. If icing is detected by one aircraft, that information can be shared with the airspace system to allow avoidance by others.

5. Detection of abnormal flight conditions (current or impending low energy or reduced control effectiveness). While this is not an icing-specific mitigation, it is included here for completeness. Either through automated sensor systems, or enhanced pilot training, the detection of abnormal low speed, deceleration, or control authority caused by icing is a powerful mitigation to avoid icing related accidents. Many accidents are in part the result of the flightcrews' lack of awareness of the state of their aircraft. This information could allow flightcrews or automated systems to properly adapt to the actual (not ideal) condition of their aircraft.

6. Recovery from icing induced upsets. By using either automated systems or enhanced pilot training, most icing related accidents could be avoided if the proper recovery maneuver/technique were utilized. This is technically difficult since it requires properly recognizing the complete state of the aircraft (upset cause, aircraft configuration, aircraft energy, propulsion capability, and existing control authority) and then properly executing the appropriate recovery maneuver/technique. For manual recovery, this may also require additional pilot training, which in turn may require high fidelity post-stall flight simulation. 


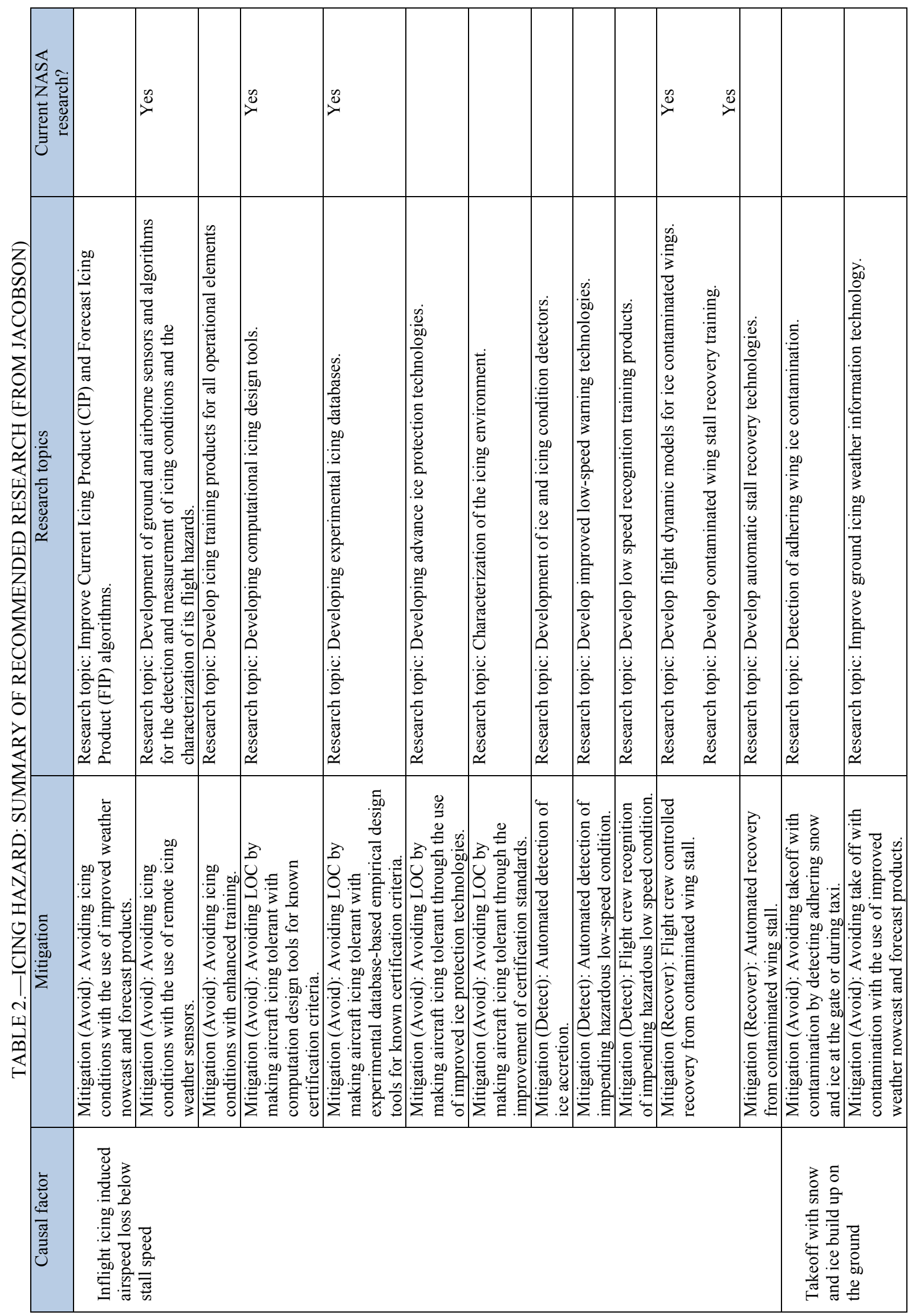




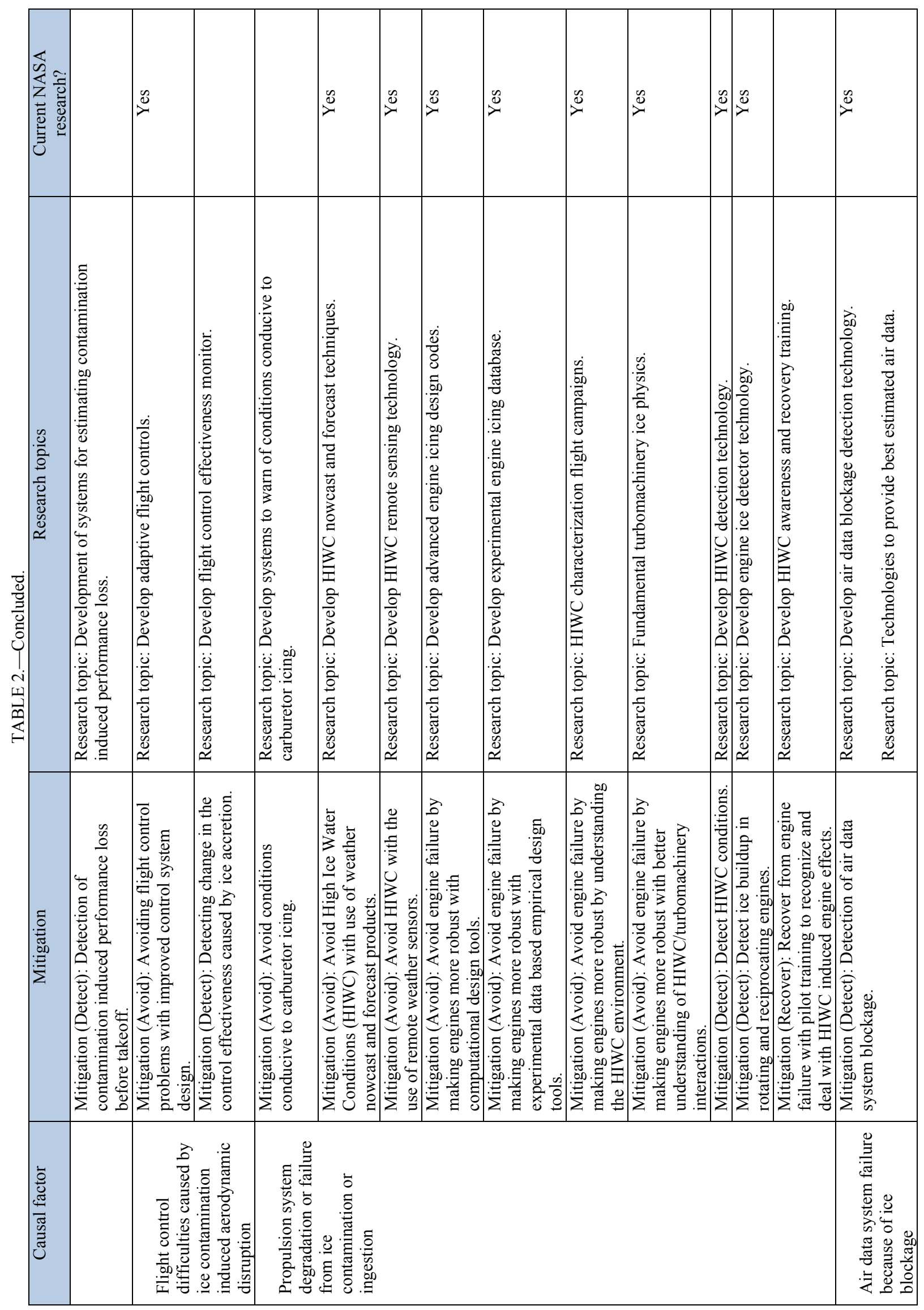




\section{NASA Aircraft Icing Research}

For more than 30 years, NASA has conducted and sponsored fundamental and applied research related to aircraft icing. The research addresses icing causes, effects, and mitigations. Historically, NASA has expended its greatest research efforts in the development of ice accretion simulation computer programs. The LEWICE codes (2-D and 3-D versions are available) are widely recognized as the standard for the modeling of inflight ice accretion on aircraft surfaces. Part of what has made these codes so widely used and recognized is that NASA has spent a great deal of effort validating the codes through experimental testing. NASA is also widely known for its ground icing facility, the Icing Research Tunnel (IRT). The IRT was originally built to answer icing questions that arose during World War II, but over the last 25 years has been continuously updated with new heat exchanger, fan drive, control, and data acquisition systems and is the busiest wind tunnel within NASA.

Building upon the strengths of its ice accretion modeling and ground testing capability, NASA has developed a broad portfolio of icing related research activities that address icing causes, effects, and mitigations. Using the LOC vocabulary, NASA Icing Research has elements addressing the avoidance, detection, and recovery from inflight icing hazards for many of the possible forms of icing hazard including inflight encounter with super-cooled cloud, with super-cooled larger droplet (SLD) conditions, and with high ice-water-content conditions, and is addressing the resultant aircraft loss of performance, loss of controllability and stability, loss of thrust, and loss of airdata systems. We will maintain the focus on avoidance, detection, and recovery mitigations by using these major elements.

\section{NASA Icing Avoidance Research Elements}

1. Avoidance of icing conditions with the use of improved weather information. By providing accurate and timely icing weather to the flight crew and other members of the aviation community (such as dispatch, air traffic control, and airport operations), icing condition encounters can be completely avoided. The two primary means of proving improved icing weather information is to develop new weather product and new sensor systems.

a. Weather product development. The current state-of-the-art FAA-approved inflight icing weather products were developed outside of NASA, but with NASA support through collaborative flight test activities. Most recently, NASA flight test efforts focused on SLD produced excellent collaborative opportunities with the weather product developers. The flight test crews at NASA Glenn Research Center (GRC) and the modeling experts at the National Center for Atmospheric Research (NCAR) collaborated so that NCAR gained in-situ validation data while the flight crews received real-time weather guidance to help locate the most intense weather conditions. Over the past several years NASA has also expanded its role by leveraging earth observing satellite expertise towards aviation needs, including inflight icing detection. The NASA Langley Research Center $(\mathrm{LaRC})$ Science Directorate is refining satellite visible and IR data channel analysis to produce high-resolution imagery-based icing products. When fully developed and validated, these weather products will provide much better guidance for the aviation community to strategically avoid areas of icing hazard while still in the flight planning phase. Currently planned flight campaigns into cruise-altitude high-concentration ice crystal environments will serve to provide the first systematic characterization effort of this potential flight hazard. Part of the flight campaign science plan objectives is to provide data for the future development of forecast products.

b. Remote sensor system development. Over the past several years, NASA GRC has developed a ground-based remote sensing technology for detecting and measuring the icing environment aloft. By combining microwave radiometers, weather radar, and lidar ceilometers, the NASA Icing Remote Sensing System (NIRSS) is able to produce vertical profiles of icing hazards directly above the ground instrumentation site that has been demonstrated to compare well with aircraftbased measurements. Leveraging Small Business Innovation Research (SBIR) Program funding, icing remote sensing technology is being extended into volume ground scanning and airborne, 
forward-looking systems. While the improved weather products described above will allow icing avoidance in the planning phase, these remote sensing instrument systems will provide flight crews the needed information for tactical rerouting during flights. As with the weather product development element, the planned flight campaigns into cruise-altitude high-concentration ice crystal environments will also contain a remote sensing research effort to provide guidance for the remote identification of this flight hazard.

2. Avoiding icing conditions with enhanced training. In the past, NASA produced a series of pilot training products that have been widely praised and utilized. These training products were developed using NASA's unique mix of multimedia development, behavioral research, and icing research skills and expertise at NASA GRC, LaRC, and Ames Research Center (ARC). NASA is currently pursuing a new level of cooperative training product development with the FAA targeting Designated Engineering Representative (DER) personnel, airline dispatchers, and other members of the aviation community that have not received targeted icing training in the past. This form of training will strengthen the decision making process related to icing hazard reduction during aircraft certification and flight planning.

3. Avoidance of icing triggered LOC by making aircraft icing tolerant with advanced design tools. By providing aircraft designers with improved design tools, aircraft can be manufactured that have greater tolerance for flight into icing conditions. The needed tools include improved ice accretion simulation for airframes and engines, improved modeling of the impact of these ice accretions on the performance and operation of aircraft and its engines, and the modeling of the impact of ice accretion on the control of aircraft. The development of these tools would allow the mitigation of avoiding icing hazards (that would otherwise lead to LOC situations) at the aircraft design phase.

a. Ice accretion simulation tools (airframe and engine). Historically, this has been the heart of the NASA GRC icing research program. The LEWICE family of programs (2-D and 3-D) is the internationally recognized standard for computational ice accretion simulation. These programs are used by aircraft and component designers to define the requirements for aircraft ice protection systems.

b. Iced aircraft performance tools (airframe and engine). Besides the modeling of the ice accretion process, aircraft designers also need to know the impact of ice accretions on the performance and operation of their aircraft and systems.

c. Control system design tools. If adequately modeled, the impact of ice accretions on the control systems of an aircraft would also allow aircraft manufacturers to design flight control systems that can appropriately adapt to control surfaces that are degraded due to ice contamination.

d. Validation databases. A robust experimental effort is required to provide the knowledge to appropriately model the ice accretion, performance, and control of aircraft in atmospheric icing conditions. These experimental capabilities are needed to range from very fine scale examinations of specific physical processes up to multicomponent interactions required to model full aircraft geometries. Besides their use for knowledge development, they are also required for validation of completed tools. These databases can also be used on their own to develop empirical rules and tools that are often extremely valuable to designers.

\section{NASA Icing Detection Research Elements}

1. Detection of icing conditions. A significant part of the NASA Aircraft Icing research effort is in the understanding, development, and use of advanced instrumentation required to characterize flight and ground simulation icing environments. This NASA capability is most often utilized by industry in the certification testing of aircraft icing protection systems and has been suggested for use as part of fleet operations. Besides in-house activities, NASA has supported commercial development of several icing environment instrumentation systems through the NASA's Small Business Innovation Research (SBIR) Program. 
2. Detection of ice accretions. NASA has traditionally supported the development of ice accretion detectors through the SBIR Program. The new engine icing research activity contains in-house efforts for developing miniature ice detectors that can be used within the harsh, high-g environment of rotating turbomachinery.

3. Detection of air data system blockage. Very recently, NASA initiated an SBIR research activity with a commercial firm to develop technologies that would allow the inflight detection of imminent air-data system failure caused by ice blockage.

\section{NASA Icing Recovery Research Elements}

1. Automated recovery from LOC with contaminated surfaces. As part of the Aviation Safety Program, Integrated Resilient Aircraft Control Project, NASA has been developing the fundamental knowledge and technologies required to automatically adapt flight controls to account for the effects of ice contamination. This adaptive control capability is a key element in the development of systems that would allow the automated LOC recovery with ice contaminated surfaces.

2. Crew controlled recovery from LOC with contaminated surfaces. NASA has also completed extensive research and development into crew-controlled recovery of several forms of ice contamination LOC, including wing stall and tail stall. As part of this effort, NASA GRC has developed a portable flight simulator with control force feedback to accurately demonstrate icing effects on flight dynamics to pilots and engineers.

\section{Summary}

As part of the 2009 to 2010 LOC Study effort, aircraft icing was identified as a significant LOC trigger that has been associated with a large percentage of LOC accidents in Part 121, 135, and 91 operations. The environmental hazard of Icing actually consists of several causal factors. These include:

1. Inflight ice accretion induced loss of performance that leads to stall and LOC

2. Ground ice contamination that prevents aircraft from reaching sufficient flight speed

3. Ice accretions that cause flight control difficulties due to degraded aerodynamics over control surfaces

4. Engine ingestion of shed ice, ingestion of high levels of ice crystals, or carburetor icing that causes airspeed loss or asymmetric thrust

5. Inflight or ground ice contamination blockage of airdata system pressure ports

Aircraft icing LOC hazards can be mitigated through avoidance, detection, or recovery. The mitigations can be broken down into the following categories:

1. Avoidance of icing conditions with the use of improved weather information

2. Avoidance of icing conditions with enhanced training

3. Avoidance of icing induced performance and controllability degradations by making aircraft more icing tolerant

4. Detection of ice build-up with sensor systems

5. Detection of abnormal flight conditions

6. Recovery from icing induced upsets 
NASA currently has a significant research effort that supports the development of these LOC mitigations. They include:

\section{Icing Avoidance Research Elements}

1. Improving icing weather information

a. Weather product development

b. Remote sensor system development

2. Improving training products and methods

3. Making aircraft more icing tolerant
a. Ice accretion simulation tool development
b. Iced aircraft performance tool development
c. Control system design tool development
d. Validation database development

\section{Icing Detection Research Elements}

1. Development of icing condition measurement technology

2. Development of ice accretion detection technology

3. Development of air data blockage detection technology

\section{Icing Recovery Research Elements}

1. Development of automated icing induced LOC recovery technologies

2. Development of crewed icing induced LOC recovery technologies

\section{References}

Pritchett, Amy R., "Charter of the ARMD/AvSP Loss-of-Control Study Team," NASA Internal Memo, Jul 2009.

Jacobson, S., Foster, J., Casner, S., Reehorst, A., Addy, E., Shah, G., and Nowinski, J., "Aircraft Loss of Control Study," NASA Internal Report, Feb. 2010.

Reveley, Mary S. et al., "Causal Factors and Adverse Conditions of Aviation Accident and Incidents Related to Integrated Resilient Aircraft Control 1988-2004," NASA TM to be published, 2009. 


\begin{tabular}{|c|c|c|}
\hline \multicolumn{2}{|c|}{ REPORT DOCUMENTATION PAGE } & $\begin{array}{l}\text { Form Approved } \\
\text { OMB No. 0704-0188 }\end{array}$ \\
\hline \multicolumn{3}{|c|}{ 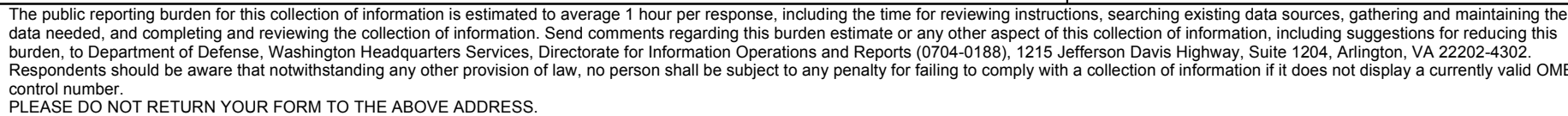 } \\
\hline $\begin{array}{l}\text { 1. REPORT DATE (DD-MM-YYYY) } \\
01-11-2010\end{array}$ & $\begin{array}{l}\text { 2. REPORT TYPE } \\
\text { Technical Memorandum }\end{array}$ & 3. DATES COVERED (From - To) \\
\hline \multirow{3}{*}{\multicolumn{2}{|c|}{$\begin{array}{l}\text { 4. TITLE AND SUBTITLE } \\
\text { Examination of Icing Induced Loss of Control and Its Mitigations }\end{array}$}} & 5a. CONTRACT NUMBER \\
\hline & & 5b. GRANT NUMBER \\
\hline & & 5c. PROGRAM ELEMENT NUMBER \\
\hline \multirow{3}{*}{\multicolumn{2}{|c|}{$\begin{array}{l}\text { 6. AUTHOR(S) } \\
\text { Reehorst, Andrew, L.; Addy, Harold, E., Jr.; Colantonio, Renato, O. }\end{array}$}} & 5d. PROJECT NUMBER \\
\hline & & 5e. TASK NUMBER \\
\hline & & $\begin{array}{l}\text { 5f. WORK UNIT NUMBER } \\
\text { WBS 609866.02.07.03.01 }\end{array}$ \\
\hline \multicolumn{2}{|c|}{$\begin{array}{l}\text { 7. PERFORMING ORGANIZATION NAME(S) AND ADDRESS(ES) } \\
\text { National Aeronautics and Space Administration } \\
\text { John H. Glenn Research Center at Lewis Field } \\
\text { Cleveland, Ohio 44135-3191 }\end{array}$} & $\begin{array}{l}\text { 8. PERFORMING ORGANIZATION } \\
\text { REPORT NUMBER } \\
\text { E-17489 }\end{array}$ \\
\hline \multirow{2}{*}{\multicolumn{2}{|c|}{$\begin{array}{l}\text { 9. SPONSORING/MONITORING AGENCY NAME(S) AND ADDRESS(ES) } \\
\text { National Aeronautics and Space Administration } \\
\text { Washington, DC 20546-0001 }\end{array}$}} & $\begin{array}{l}\text { 10. SPONSORING/MONITOR'S } \\
\text { ACRONYM(S) } \\
\text { NASA }\end{array}$ \\
\hline & & $\begin{array}{l}\text { 11. SPONSORING/MONITORING } \\
\text { REPORT NUMBER } \\
\text { NASA/TM-2010-216912 }\end{array}$ \\
\hline \multicolumn{3}{|c|}{$\begin{array}{l}\text { 12. DISTRIBUTION/AVAILABILITY STATEMENT } \\
\text { Unclassified-Unlimited } \\
\text { Subject Category: } 03 \\
\text { Available electronically at http://gltrs.grc.nasa.gov } \\
\text { This publication is available from the NASA Center for AeroSpace Information, 443-757-5802 }\end{array}$} \\
\hline
\end{tabular}

\section{SUPPLEMENTARY NOTES}

\section{ABSTRACT}

Factors external to the aircraft are often a significant causal factor in loss of control (LOC) accidents. In today's aviation world, very few accidents stem from a single cause

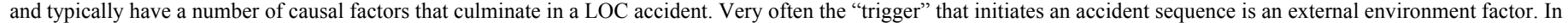
a recent NASA statistical analysis of LOC accidents, aircraft icing was shown to be the most common external environmental LOC causal factor for scheduled operations. When investigating LOC accident or incidents aircraft icing causal factors can be categorized into groups of 1) in-flight encounter with super-cooled liquid water clouds, 2) take-off with ice contamination, or 3) in-flight encounter with high concentrations of ice crystals. As with other flight hazards, icing induced LOC accidents can be prevented

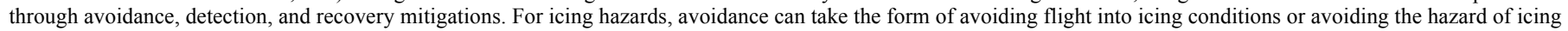

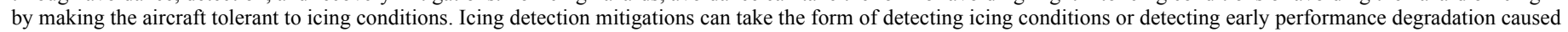

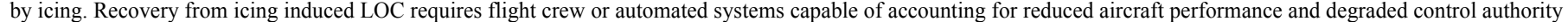

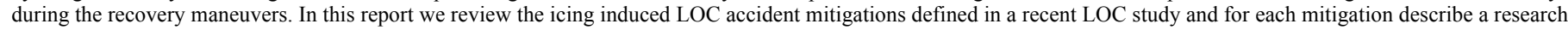
topic required to enable or strengthen the mitigation. Many of these research topics are already included in ongoing or planned NASA icing research activities or are being addressed by members of the icing research community. These research activities are described and the status of the ongoing or planned research to address the technology needs is discussed.

15. SUBJECT TERMS

Aircraft icing; Aircraft safety; Aircraft control; Accident prevention; NASA programs

\begin{tabular}{|c|c|c|c|c|c|}
\hline \multicolumn{3}{|c|}{ 16. SECURITY CLASSIFICATION OF: } & \multirow{2}{*}{$\begin{array}{l}\text { 17. LIMITATION OF } \\
\text { ABSTRACT } \\
\text { UU }\end{array}$} & \multirow{2}{*}{$\begin{array}{l}\text { 18. NUMBER } \\
\text { OF } \\
\text { PAGES } \\
16\end{array}$} & \multirow{2}{*}{$\begin{array}{l}\text { 19a. NAME OF RESPONSIBLE PERSON } \\
\text { STI Help Desk (email:help@sti.nasa.gov) } \\
\text { 19b. TELEPHONE NUMBER (include area code) } \\
\text { 443-757-5802 }\end{array}$} \\
\hline $\begin{array}{l}\text { a. REPORT } \\
U\end{array}$ & $\begin{array}{l}\text { b. ABSTRACT } \\
\text { U }\end{array}$ & $\begin{array}{l}\text { c. THIS } \\
\text { PAGE } \\
\text { U }\end{array}$ & & & \\
\hline
\end{tabular}



